\title{
HBV-Induced Immune Imbalance in the Development of HCC
}

\author{
Yongyan Chen ${ }^{1,2 *}$ and Zhigang Tian ${ }^{1,2}$ \\ ${ }^{1}$ Hefei National Laboratory for Physical Sciences at Microscale, The CAS Key Laboratory of Innate Immunity and Chronic \\ Disease, Division of Molecular Medicine, School of Life Sciences, University of Science and Technology of China, Hefei, \\ China, ${ }^{2}$ Institute of Immunology, University of Science and Technology of China, Hefei, China
}

OPEN ACCESS

Edited by:

Yuan Quan,

Xiamen University, China

Reviewed by:

Cai Zhang,

Shandong University, China

Dong Zhang,

Nankai University, China

${ }^{*}$ Correspondence:

Yongyan Chen

yychen08@ustc.edu.cn

Specialty section: This article was submitted to

Viral Immunology,

a section of the journal

Frontiers in Immunology

Received: 13 June 2019 Accepted: 13 August 2019

Published: 27 August 2019

Citation:

Chen Y and Tian Z (2019) $\mathrm{HBV}$-Induced Immune Imbalance in the Development of HCC.

Front. Immunol. 10:2048.

doi: 10.3389/fimmu.2019.02048
Chronic hepatitis B virus (HBV) infection is one of the high-risk factors for human HCC. Despite the integration of virus DNA and the oncoprotein $\mathrm{HBx}$, chronic necroinflammation and hepatocellular regeneration account for hepatocarcinogenesis. As a non-cytopathic virus, HBV is extensively recognized to mediate chronic liver damage through abnormal immune attack. However, the mechanisms driving HBV infection to HCC are poorly understood. During chronic HBV infection in humans, the adaptive immunity changes from immune tolerance to progressive immune activation, inactivation, reactivation and exhaustion, all of which may be the immune pathogenic factors for the development of HCC. Recently, the immunopathogenic mechanisms were described in mouse HBV-induced HCC models, which is absolutely dependent on the presence of HBV-specific T cell response and NK cell-derived IFN- $\gamma$, findings which are consistent with the observations from $\mathrm{CHB}$ and $\mathrm{HCC}$ patients. In this review, we summarize recent research progression on the HBV-specific $\mathrm{CD}^{+}{ }^{+} \mathrm{T}$ cells, and also $\mathrm{CD} 4^{+} \mathrm{T}$ cells, B cells and non-specific immune cells and molecules underlying chronic HBV infection and eventual HCC development to demonstrate the pathogenesis of HBV-induced immune imbalance. Based on the progression, we discussed the potential of immune-based therapies and their challenges in the treatment of HBV-related HCC, including the checkpoint inhibition, genetically modified $T$ cell transfer, therapeutic vaccines and metabolic modulation.

Keywords: HBV, immune dysfunction, HCC, adaptive immunity, innate immunity

\section{INTRODUCTION}

Chronic hepatitis B virus (HBV) infection is one of the high-risk factors for human HCC, responsible for $50 \sim 80 \%$ of HCC cases worldwide. As one of the leading causes of cancer death, HCC represents an important human health problem (1). It has been an urgent issue how chronic HBV infection promotes hepatocarcinogenesis. In adults, HBV infection causes a rapid immune response, typically resulting (more than $95 \%$ patients) in life-long immunity with acute self-limited infection; while in infants and children, HBV infection has the potential to become chronic with life-long HBV persistence (2).

Despite the direct gene activation and transactivation by the integration of $\mathrm{HBV}$ DNA into hepatocyte genome and the oncoprotein $\mathrm{HBx}$ and preS/S, HBV-inflicted DNA damage due to hepatocellular regeneration associated with chronic necroinflammation accounts for hepatocarcinogenesis (3-6). In the cytoplasm of infected hepatocytes, HBV has its own nucleocapsids in which HBV completes its replication as a stealth virus without type I IFN-mediated responses (2). As a non-cytopathic virus, HBV-induced 
liver damage is extensively recognized to be mediated by abnormal immune attack. A dynamic balance between immune clearance and immune tolerance accounts for the outcome in patients with chronic HBV infection. It has been increasingly accepted that immunopathogenesis plays a critical role in HBVrelated HCC development; however, the precise mechanisms by which $\mathrm{HBV}$ drives to HCC remain poorly understood. Here, the recent progress was summarized in understanding the adaptive and innate immune responses underlying chronic HBV infection that can lead to HCC development and examine the critical pathogenesis of HBV-induced immune imbalance. Further, the cross-talk and network regulation among these immune cells and their released key factors was discussed. Additionally, we discuss the potential of immune-based therapies and their challenges for HBV-related HCC.

\section{Immune Response Is Related to Disease Progress During HBV Infection}

During self-limited acute $\mathrm{HBV}$ infection, the efficient HBVspecific immune response is essential. A vigorous response of $\mathrm{CD}^{+} \mathrm{T}$ and $\mathrm{CD}^{+} \mathrm{T}$ cells was generated to control and clear $\mathrm{HBV}$. HBV-specific $\mathrm{CD}^{+} \mathrm{T}$ cells exhibit antiviral activity by producing IFN- $\gamma$ and $\operatorname{TNF}-\alpha(7,8)$ or by directly killing the infected hepatocytes (9-11). B cells are co-stimulated by $\mathrm{T}$ cells and subsequently produce antibodies to $\mathrm{HBV}$ surface antigen (HBsAg), $\mathrm{HBV}$ e antigen (HBeAg) and $\mathrm{HBV}$ core antigen (HBcAg). These antibodies act to clear antigens and HBV virus from the circulation, preventing or limiting HBV reinfection (12). In addition, NK cells and NKT cells efficiently control HBV, the activities of which peak earlier than that of $\mathrm{HBV}$-specific $\mathrm{T}$ cells (12).

During chronic HBV infection, the early phase termed "immune tolerant" stage with a high-replication of HBV-DNA and low-inflammation during childhood (13). The progressive loss of immune tolerance leads to the "immune active" stage with $\mathrm{HBV}$-specific $\mathrm{CD}^{+} \mathrm{T}$ cell responses during adolescence, which results in chronic liver injuries, inflammation and liver regeneration. Patients may subsequently enter an "immune inactive" stage with low level of HBV replication and limited inflammation. Particularly, approximately $20 \sim 30 \%$ of patients in the inactive carrier stage are subject to a viral relapse, displaying replicative $\mathrm{HBV}$ and thus enter the "immune reactive" stage with chronic hepatitis that progress to liver fibrosis, cirrhosis and HCC. In the late stage, a series of oncogenic signaling pathways activated by $\mathrm{HBV}$ result in immune escape, and promotes the finally developing HCC (14). More recently, studies show that HBV-immunotolerant patients develop HCC $(\sim 12 \%$ in 10 years $)$, while treated "immune active" patients develop HCC ( $\sim 6 \%$ in 10 years $)$ with a lower rate. Notably, patients with more cumulative immunemediated hepatocyte damage would be more susceptible to
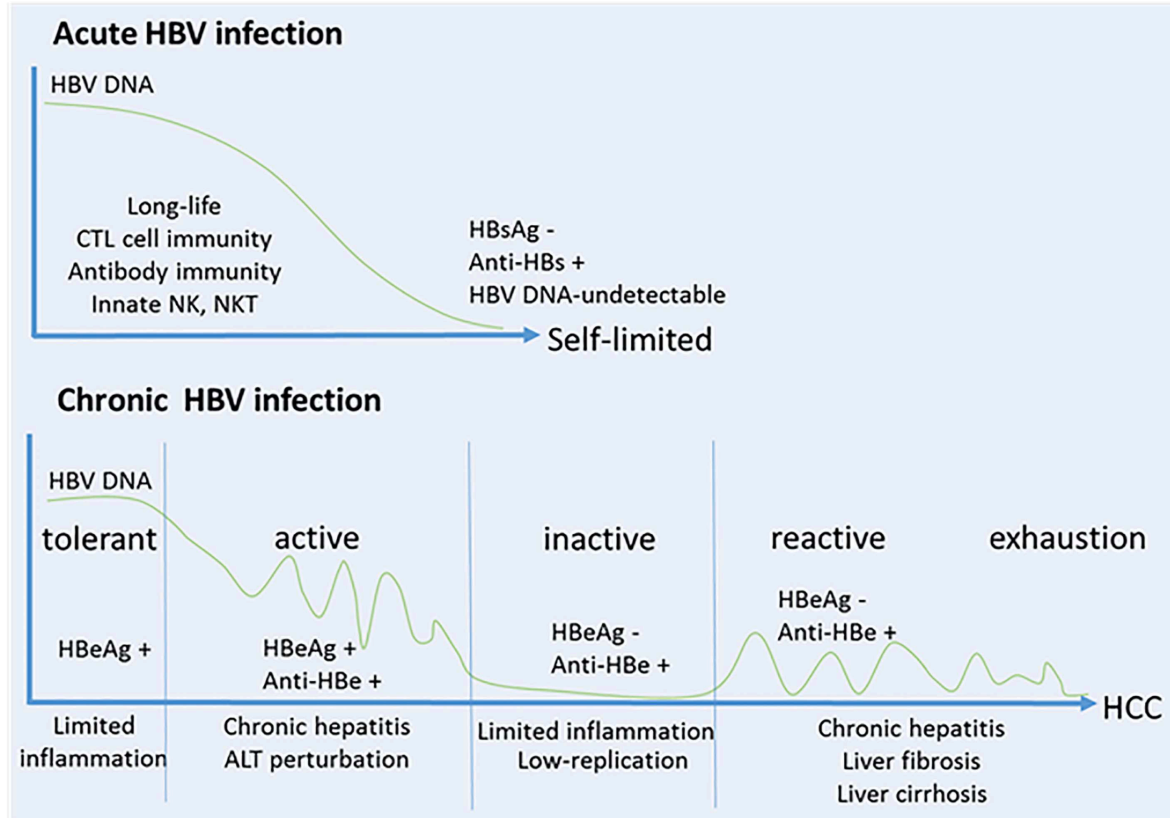

FIGURE 1 | HBV infection relates to the magnitude and quantity of anti-viral immune response. (A) Self-limited acute HBV infection. NK cells and NKT cells play important roles in early control of $\mathrm{HBV}$, and then a robust response of $\mathrm{CD} 4^{+} \mathrm{T}$ cells and $\mathrm{CD} 8^{+} \mathrm{T}$ cells is generated to control and eliminate $\mathrm{HBV}$. B cells co-stimulated by $\mathrm{T}$ cells produce anti-HBs, anti-HBe and anti-HBc. These protective antibodies clear HBV antigens and virus from the circulation, and prevent or limit HBV reinfection. (B) Chronic HBV infection. Five stages are identified including "immune tolerant" stage with a high-replication of HBV-DNA and low-inflammation, "immune active" stage with HBV-specific CD8 ${ }^{+} \mathrm{T}$ cell response and antibody production which results in chronic liver injuries, inflammations and liver regeneration, "immune inactive" stage with low-replication of HBV and limited inflammation, "immune reactive" stage with chronic hepatitis progressed to liver fibrosis, cirrhosis and HCC, and in the late stage of "immune exhaustion." 


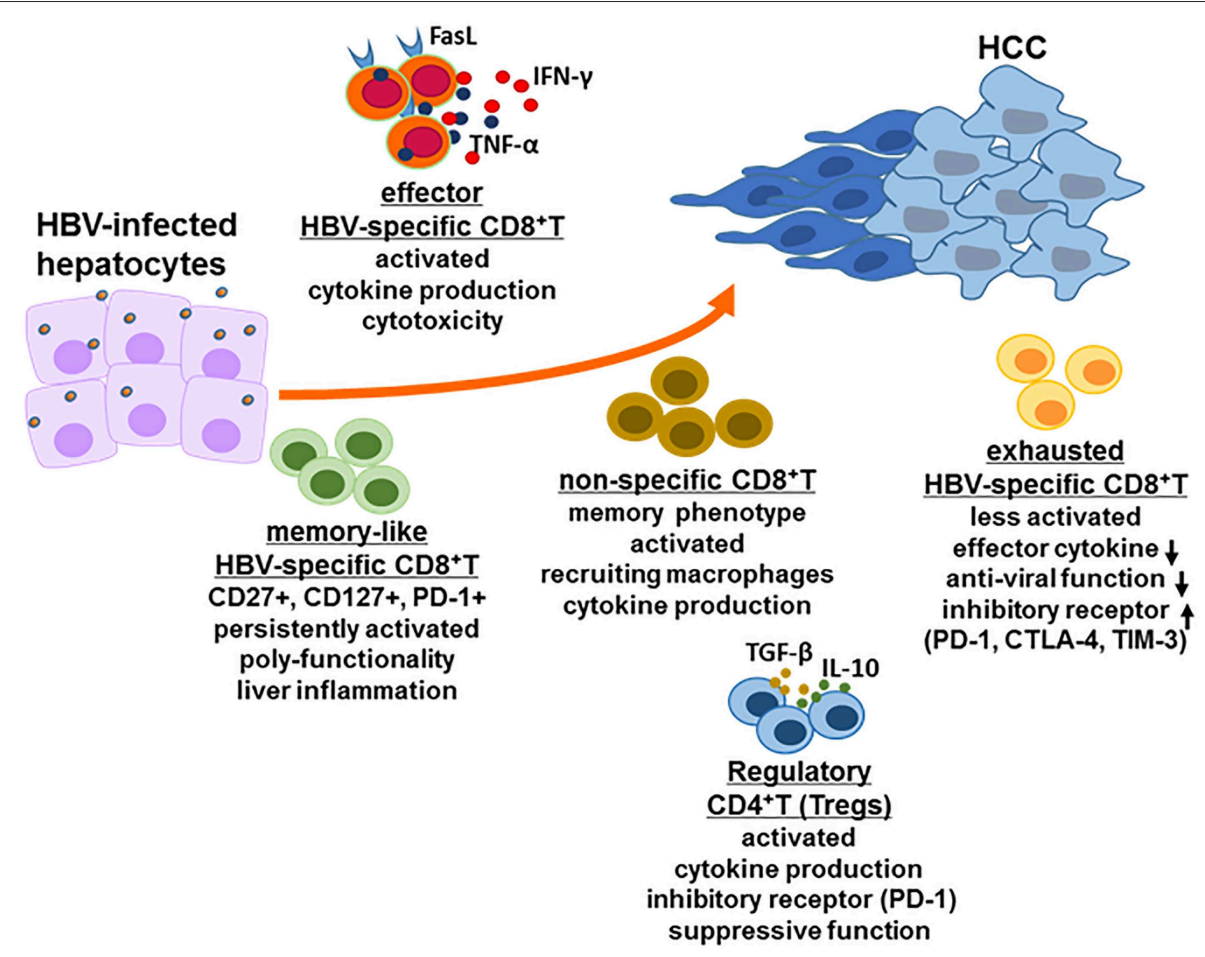

FIGURE 2 | CD8 ${ }^{+}$T cell response in HBV-related HCC. In the HBV-infected individuals, there are several kinds of CD8 ${ }^{+} \mathrm{T}^{\mathrm{C}}$ cell populations including exhausted HBV-specific CD8 ${ }^{+} \mathrm{T}$ cells, HBV core-specific and polymerase-specific CD8 ${ }^{+} \mathrm{T}$ cells with long-term memory-like phenotype, effector CD8 ${ }^{+} \mathrm{T}_{\text {cells }}$ and HBV non-specific $\mathrm{CD}^{+} \mathrm{T}$ cells. The function of each $\mathrm{CD}^{+} \mathrm{T}$ cell population is different but possibly promote the development of HCC together. Additionally, regulatory $\mathrm{CD}^{+}{ }^{+} \mathrm{T}$ cells (Tregs) also play a critical role in the stage of HCC for immune escape, for example inducing CD8 ${ }^{+} \mathrm{T}^{\mathrm{c}}$ cell exhaustion.

HCC $(15,16)$. The patient consequences of HBV infection relate to the magnitude and quantity of anti-HBV immune responses (Figure 1). As one of the hallmarks of cancer, chronic inflammation is considered to be an important element and contributes to changing the tumor microenvironment during this process (17).

\section{HBV-Specific CD8 ${ }^{+} \mathrm{T}$ Cell Response in HBV-Related HCC}

During acute $\mathrm{HBV}$ infection, potent $\mathrm{HBV}$-specific $\mathrm{CD}^{+} \mathrm{T}$ cell responses control $\mathrm{HBV}$, typically reducing its titer to undetectable levels. Furthermore, HBV-specific memory T cells with an activated phenotype was persistent after resolving acute HBV infection (18). However, during chronic HBV infection, $\mathrm{HBV}$ replication levels as ranging from $10^{3}$ to $10^{9} \mathrm{HBV}$ DNA copies/mL in peripheral blood of patients with chronic HBV, significantly affected $\mathrm{HBV}$-specific $\mathrm{CD}^{+}{ }^{+} \mathrm{T}$ cell responses. $\mathrm{HBV}$ DNA load of $10^{7}$ copies $/ \mathrm{ml}$ was suggested as a threshold, below which multiple $\mathrm{HBV}$-specific $\mathrm{CD}^{+} \mathrm{T}$ cells, including env-specific, pol-specific and core-specific $\mathrm{CD}^{+} \mathrm{T}$ cells are consistently detected in the peripheral blood; while above the threshold of $\mathrm{HBV}$ replication level, env-specific $\mathrm{CD} 8^{+} \mathrm{T}$ cells and pol-specific $\mathrm{CD}^{+} \mathrm{T}$ cells can occasionally be found (19). The role and function of highly heterogeneous $\mathrm{HBV}$-specific $\mathrm{CD} 8^{+} \mathrm{T}$ cell are diverse in the development of HBV-related HCC (Figure 2).
The decrease of $\mathrm{HBV}$-specific $\mathrm{CD}^{+} \mathrm{T}$ cell functions in $\mathrm{CHB}$ patients is mainly shown by the low frequency due to antigen-specific deletion and restricted proliferation, and also the high expression levels of inhibitory receptors such as CTLA4, PD-1, and TIM-3 (12, 20-23). The higher expression levels of TIM-3 in active $\mathrm{CHB}$ patients compared to inactive $\mathrm{CHB}$ patients suggest that $\mathrm{CD} 8^{+} \mathrm{TIM}-3^{+} \mathrm{T}$ cells are functionally exhausted during the active state of chronic HBV infection (24). Oncofetal gene SALL4 reactivation by HBV-induced STAT3 signal in adulthood counteracts miR-200c, which accounted for PD-L1-induced $\mathrm{CD}^{+} \mathrm{T}$ cell exhaustion (25). Exhausted $\mathrm{CD}^{+} \mathrm{T}$ cells were unable to effectively produce cytokines and exert anti-viral activity when re-exposure to $\mathrm{HBV}$ in an acute immune active state, indicating that exhausted $\mathrm{CD}^{+}{ }^{+} \mathrm{T}$ cells displaying dysfunctional differentiation are associated with chronic HBV replication and the resulting disease progression (26). Furthermore, $\mathrm{CD}^{+}$resident memory T cells (TRM) were enriched with higher expression levels of PD-1 in the tumor tissue of HBV-related HCC, which were functionally more suppressive and exhausted (27). Single-cell RNA-sequencing demonstrated that there was higher frequency of exhausted $\mathrm{CD}^{+} \mathrm{T}$ cells and regulatory $\mathrm{T}$ cells (Tregs) with clonally expansion in HCC patients, and layilin (LAYN) was related to the suppressive function of Tregs and exhausted $\mathrm{CD} 8^{+} \mathrm{T}$ cells in HCC (28). 
In addition to the inhibitory pathways, a more complex mechanism of energetic and metabolic impairment accounted for $\mathrm{CD}^{+} \mathrm{T}$ cell exhaustion during $\mathrm{HBV}$ infection. In patients with chronic $\mathrm{HBV}$ infection, exhausted $\mathrm{HBV}$-specific $\mathrm{CD}^{+} \mathrm{T}$ cells with high ROS level showed extensive downregulation of mitochondrial functions including electron transport, $\mathrm{mt}$ DNA transcription and translation, membrane transport and metabolism, and marked downregulation of proteasome subunits and proteins involved in DNA repair (29). Additionally, HBx protein dysregulated glucose metabolism with increased lactate production, which impaired the migration of $\mathrm{T}$ cells in the liver and their cytolytic activity (30).

Recently, numerous $\mathrm{HBV}$-specific $\mathrm{T}$ cell populations including $\mathrm{HBV}$ core-specific and $\mathrm{HBV}$ polymerase-specific $\mathrm{CD}^{+} \mathrm{T}$ cells were detected in the circulation of $\mathrm{CHB}$ patients, and these cells exhibited a long-term memory-like phenotype and poly-functionality, which was not terminally exhausted (31-34). Clinical observation demonstrated that when residual antigen-specific $\mathrm{CD}^{+} \mathrm{T}$ cells were persistently activated but unable to control HBV replication, they might contribute to sustain liver inflammations predisposing patients to HCC development $(11,13,15,16,19)$.

To reveal the exact immunopathogenic mechanisms of $\mathrm{CD}^{+} \mathrm{T}$ cells in HBV-related HCC, murine HBV-induced HCC models were generated for analysis. In 1998, Nakamoto et al. $(35,36)$ demonstrated that HBsAg-specific cytotoxic $\mathrm{T}$ lymphocytes (CTLs) constantly attacked HBsAg-expressing hepatocytes, eventually triggering $\mathrm{HCC}$ in $\mathrm{HBV}$ transgenic mice via thymectomy, bone marrow reconstruction and adoptive transfer of splenic HBsAg-specific $\mathrm{CD}^{+} \mathrm{T}$ cells from HBsAg-immunized mice. Using this model, they further demonstrated that use of an anti-FasL neutralizing antibody could attenuate the hepatotoxicity of HBsAg-specific CTLs and prevented the chronic hepatitis and eventual HCC (36). Studies in our lab have also illustrated that breakdown of adaptive immune tolerance by blockade of TIGIT ( $\mathrm{T}$ cell immunoglobulin and ITIM domains, a checkpoint receptor involved in mediating $\mathrm{T}$ cell exhaustion in tumors) combined with HBsAg vaccination is able to recover the anti-HBV function of autologous HBsAg-specific CTLs including IFN$\gamma$ and TNF- $\alpha$ prodction, which was responsible for mediating HCC progression in HBs-Tg mice (37). To mimick naturally occurring anti-HBV immunity and immunopathology, we generated a novel $\mathrm{HBV}$ mouse model by transferring $\mathrm{HBsAg}^{+}$ hepatocytes from HBs-Tg mice into an immunocompetent recipient mouse $\left(\mathrm{Fah}^{-/-}\right.$mouse) with the same genetic background. In this mouse model, HBsAg-specific $\mathrm{CD}^{+} \mathrm{T}$ cells were naturally generated and responsible for mediating hepatocyte apoptosis and chronic hepatitis, eventually leading to HCC (unpublished data).

Additionally, non-specific $\mathrm{CD}^{+} \mathrm{T}$ cells with memory phenotypes secreted IFN- $\gamma$ when activated by antiCD137 $\mathrm{mAb}$ in $\mathrm{HBV}$ transgenic mice, and played a central role in the subsequent development of chronic inflammation, fibrosis, cirrhosis and HCC progression. During this process, non-specific $\mathrm{CD}^{+} \mathrm{T}$ cells preferentially recruited hepatic macrophages, which promoted the development of HCC through secreting TNF- $\alpha$, IL-6, and MCP-1 (38). In patients with chronic HBV infection, circulating $\mathrm{CD}^{+}{ }^{+}$monocytes with elevated expression of the natural ligand of CD137 might contribute to the sustained CD137 stimulation of $\mathrm{CD}^{+} \mathrm{T}$ cells for the liver immunopathology (38).

\section{HBV-Specific CD4 ${ }^{+} \mathrm{T}$ Cell Response in HBV-Related HCC}

$\mathrm{CD}^{+}{ }^{+} \mathrm{T}$ cells are considered to contribute to anti-viral and antitumor immune responses by producing cytokines that activate $\mathrm{CD}^{+} \mathrm{T}$ cells and B cells. Patient circulating and liver-infiltrating $\mathrm{CD} 4^{+}$CTLs were increased in the early stage of HCC, which was significantly higher than that of CHB patients (39). This finding indicated that chronic HBV infection may not be the principal element accounting for the observed increase in $\mathrm{CD}_{4}^{+}$ CTLs in HBV-related HCC. Both $\mathrm{CD}^{+}{ }^{+}$CTL number and activity decreased in progressive stages of HCC due to the increased Tregs, and the progressive deficit in $\mathrm{CD}^{+}$CTLs was linked to the high recurrence and poor survival of HCC patients (39).

Tregs are known to exert their suppressive function via cellto-cell contact or through cytokines such as IL-2, IL-10, TGF$\beta$, and IL-35 (40). Noticeably, in HBV-related HCC patients, Tregs were enriched and showed greater expression of PD-1 with increased suppressive function, which accounted for the more immunosuppressive and exhausted microenvironment of HBV-related HCC compared to the non-virus-related HCC (27). Increased Tregs in HBV-related HCC patients have also been implicated in the reduction of the function of $\mathrm{CD}^{+} \mathrm{T}$ cells, as demonstrated by the inhibited proliferation and activation of $\mathrm{CD}^{+} \mathrm{T}$ cells and attenuated cytotoxicity of $\mathrm{CD} 8^{+} \mathrm{T}$ cells with less production of granzymeA/B and perforin (41). Persistent presence of HBV led to elevated TGF- $\beta$ which suppressed miR34 a expression and enhanced CCL22 expression, thus recruiting Tregs in the liver tissue (42). Tregs facilitated the immune escape of $\mathrm{HBV}^{+} \mathrm{HCC}$, resulting in the development of portal vein tumor thrombus in HCC patients (42). The increased Tregs not only suppressed HBV antigen-specific immune responses, but also suppressed HCC tumor antigen-specific immune responses (43). Further, it was found that compared with the healthy donors and patients of chronic HBV infection, the frequency of circulating $\mathrm{CD} 4{ }^{+} \mathrm{CD} 25^{+} \mathrm{CD} 127^{-}$Tregs was much lower in HCC patients, but surgery resulted in significantly increasing the frequency of circulating $\mathrm{CD} 4{ }^{+} \mathrm{CD} 25^{+} \mathrm{CD} 127^{-}$Tregs in $\mathrm{HCC}$ patients, correlating with tumor aggressiveness (44). These results suggest a therapy targeted to reduce Treg activity may prove beneficial for HCC patients (45).

The frequency of circulating $\mathrm{CD} 4^{+} \mathrm{T}$ follicular helper cells $\left(\mathrm{CXCR} 5^{+} \mathrm{CD} 4^{+} \mathrm{Tfh}\right)$ decreased and their function was impaired with disease progression in HBV-related HCC patients (46). Further, the infiltrated $\mathrm{CXCR} 5{ }^{+} \mathrm{CD} 4{ }^{+} \mathrm{T}$ cells was demonstrated to be significantly less in HCC tumor regions than that of nontumor regions (46). These Tfh cells from HCC patients resulted in less effective induction of the differentiation of plasmablasts from naive B cells, since they reduced ICOS expression and the ability to produce IL-10 and IL-21 with less proliferation activity (47). 


\section{HBV-Specific B Cell and Antibody Responses in HBV-Related HCC}

In patients of HBV infection, serological biomarkers changed from $\mathrm{HBsAg}^{+}$and $\mathrm{HBeAg}^{+}$to anti- $\mathrm{HBs}^{+}$and anti- $\mathrm{HBe}^{+}$ are used to describe the recovery of HBV infection. HBV is never completely eliminated from the patients system, due to the persistence of a little of covalently closed circular DNA (cccDNA) and integrated DNA of HBV in infected individuals (18). The integrated DNA can express HBV antigens including HBsAg. It is increasingly recognized that humoral immune responses involving anti-HBs antibody production exhibit an important activity in the process of controlling $\operatorname{HBV}(48,49)$. Lack of effective $B$ cell and neutralizing antibody responses promote the disease progression of chronic $\mathrm{HBV}$ infection (48). Recently, fluorochromes-labled HBsAg was utilized as "baits" to specifically detect HBsAg-specific B cells in vitro by using a dual-staining method. Studies by using this method demonstrated that there was no significant difference in the number of circulating HBsAg-specific B cells among patients with chronic HBV infection, patients with acute HBV infection and vaccinated subjects. Furthermore, the frequency of HBsAgspecific $B$ cells did not correlate to the quantity of HBsAg or HBV-DNA during chronic HBV infection (50). B cells from CHB patients exhibit an atypical phenotype $\left(\mathrm{CD} 21^{-} \mathrm{CD}_{2} 7^{-}\right)$and show functional alterations with PD-1 expression, resulting in the reduction of antibody production $(50,51)$. When supplemented with cytokine (IL-2 and IL-21) signals and costimulatory signalsderived from CD40L-expressing feeder cells, the maturation of these HBsAg-specific B cells from CHB patients could be partially restored; and functional blockade of the PD-1 expressed on these HBsAg-specific B cells could partially rescue their functions $(50,51)$. Depletion of B cells by antibody treatment reactivated $\mathrm{HBV}$ in patients with chronic $\mathrm{HBV}$ infection with a high rate to $60 \%$, even in the subjects with resolved infection years earlier, and this reactivation may lead to severe disease (52).

Beyond the production of HBV-specific antibodies, significantly higher frequencies of IL-10-expressing B cells (Bregs) were observed in HCC patients than that of healthy controls. Furthermore, these Bregs preferentially expressed TIM1 , negatively correlating with the expression of granzyme A/B and perforin in $\mathrm{CD}_{4}^{+} \mathrm{T}$ cells (53). The different immune phases of patients with chronic HBV infection changes in the Breg frequency, with elevated serum levels of IL-10 observed in the immune active patients when compared to the immune tolerant patients (54). Additionally, the frequency of circulating Bregs was significantly increased after surgery, which was associated with the levels of HBeAg and HBV-DNA copy number (44). These results suggest a potential therapy against Bregs may offer improved outcomes for HCC patients.

\section{Innate Immune Responses in HBV-Related HCC}

The liver as a lymphoid organ has an overwhelming innate immune system, including several kinds of innate immune cells with high frequency such as NK and NKT cells (55-57). Among total intrahepatic lymphocytes, the frequency of NK cells is as high as $25-40$ and $10-20 \%$ in human and mouse livers, respectively. It is well-known that NK cells exhibit early antiviral and anti-tumor activities (58); however many mechanisms are involved in the alterations of NK cell functions during the progression of $\mathrm{HBV}$ infection.

NK cells participate in controlling HBV replication in mice (59), but within patients with chronic HBV infection their anti-viral activity is suppressed in the presence of IL-10 and transforming growth factor $\beta$ (TGF- $\beta$ ) (60). Further, in NK cells from patients with chronic HBV infection, inhibitory receptors NKG2A, TIM-3, and PD-1 expression was up-regulated and the ability of IFN- $\gamma$ and TNF- $\alpha$ secretion was reduced, which was involved in the HCC progression (61-63). Additionally, HBV was reported to secrete exosomes, which play a critical role in mediating HBV transmission in NK cells and consequently impairing NK cell functions, proliferation and survival (61). Furthermore, compared with healthy individuals, NK cells from CHB and HCC patients show significant increases in the expression of microRNA (miR)-146a, which related to the downregulation of NK cell function including reduced cytotoxicity and decreased IFN- $\gamma$ and TNF- $\alpha$ production (64). In HCC patients, the presence of infiltrating $\mathrm{CD}_{11 b^{-} \mathrm{CD} 27^{-}}$ NK subsets in the tumor origins was positively correlated with the clinical outcomes, since a substantial proportion of these cells exhibited inactive and immature phenotypes with weak cytotoxicity and poor IFN- $\gamma$ production (63). In addition to their anti-viral and anti-tumor activities, activated NK cells may also mediate HBV-associated hepatocyte damage (56, 65). Recently, our study demonstrated that NK cells mediate liver inflammation by secreting IFN- $\gamma$, which promote the development of HCC through the epithelial cell adhesion molecule (EpCAM)-epithelial cell to mesenchymal transition (EMT) axis in HBs-Tg mice (66). In HCC patients, increased levels of IFN- $\gamma$ also mediated liver dysfunction and associated with HCC progression (67).

Activation of non-virus-specific cells may result in widespread inflammation, promoting HCC development. NKT cells promoted hepatic stellate cells (HSCs) activation in liver fibrogenesis through producing the inflammatory cytokines IL-4 and IL-13, accounting for the spontaneous liver fibrosis in HBV-Tg mice (68). HSCs upregulated the level of Tregs in the liver, which was involved in the occurrence of HCC following fibrosis and cirrhosis (69). Activation of NKT cells could be augmented by CD205 ${ }^{+}$Kupffer cells through IL-12 production during HBV infection (70). Hepatic macrophages recruited by $\mathrm{CD} 8^{+} \mathrm{T}$ cell-derived IFN- $\gamma$ subsequently produced TNF- $\alpha$, IL- 6 and MCP-1 to mediate chronic hepatits and HCC progression (38). Circulating $\mathrm{CD}^{+} 4^{+}$monocytes may contribute to the activation of $\mathrm{CD} 8^{+} \mathrm{T}$ cells through CD137 ligand upregulation in patients with chronic HBV infection (38). Ly6C $\mathrm{C}^{+}$monocytes-secreted TNF- $\alpha$ also played the critical role in enhacing $\mathrm{CD}^{+} \mathrm{T}$ cell response for $\mathrm{HBV}$ clearance (71). Althogh hepatic macrophages promote the development of HCC during chronic HBV infection, they have also shown opposite roles. Kupffer cell-derived IL-10 operates to maintain humoral immune tolerance and induce anti-HBV $\mathrm{CD} 8^{+} \mathrm{T}$ 
cell exhaustion in chronic HBV carrier $(72,73)$. Additoanlly, maternal HBeAg-predisposed hepatic macrophages may mediate immune tolerance to HBV (74).

As an important population of liver-resident innate immune cells, $\gamma \delta \mathrm{T}$ cells-drived myeloid-derived suppressor cell (MDSC) accumulation in the HBV-tolerant liver strongly suppressed $\mathrm{CD}^{+} \mathrm{T}$ cell function and promoted systemic $\mathrm{CD} 8^{+} \mathrm{T}$ cell exhaustion (75). Recent stuidies demonstrated the circulating $\gamma \delta \mathrm{T}$ cells showed distinct phenotypes and functions with higher frequency of T-bet ${ }^{\mathrm{hi}} \mathrm{Emos}^{\mathrm{dim}} \mathrm{V} \delta 2^{+} \gamma \delta \mathrm{T}$ cells in patients of chronic HBV infection compared with uninfected control subjects (76). Further, IFN $\gamma / \mathrm{TNF}$ responses were weaker in $\mathrm{V} \delta 2^{+}$ $\gamma \delta \mathrm{T}$ cells from chronic HBV infected patients with hepatitis flare when compared to those without hepatitis flare (76).

Complement system is a vital part of the innate immune system, comprising a variety of different proteins including complements, complement receptors and the regulatory protein. In CHB patients, elevated C5a promoted HSC activation and inhibited HSC apoptosis, which positively correlated with disease severity demonstrated by the clinical parameters of liver fibrosis (77). Gene polymorphisms of complement receptor 1 (CR1) contributed to the risk of HBV-related HCC in males (78). Additionally, HBx increased the expression of complement regulatory protein $\mathrm{CD} 59$, which prevented the formation of terminal membrane attack complex C5b-9 on the hepatoma cells (79). Thus, the dysregulation of complement system induced by chronic HBV infection promoted the development of HCC in several manners.

\section{Cross-Talk and Regulation Among Different Immune Cells in HBV-Related HCC}

$\mathrm{HBV}$-induced immune imbalance leads to the development of HCC as described above. We further summarized the HBVinduced changed immune cells and their released cytokines (Table 1). Complicated cross-talk and regulation among these immune cells further makes it difficult to control and regulate the immune disorders. A variety of cytokines and other molecules are involved in this process (Figure 3). When these immune cells including $\mathrm{CD} 4^{+} \mathrm{T}, \mathrm{CD} 8^{+} \mathrm{T}$, NK, NKT, monocytes/macrophages, and HSCs are activated, they participate in mediating the liver inflammation during chronic HBV infection, which eventually promote the development of HCC. Moreover, interactions among these activated cells through producing cytokines such as TNF- $\alpha$, IFN- $\gamma$, IL-12, IL-4, and IL-13 aggravate the chronic hepatitis $(38,68,70)$. On the other hand, several kinds of immunosuppressive cells including Treg, Breg, MDSC, and Kupffer cells negatively regulate those activated immune cell especially by producing cytokines such as TGF- $\beta$ and IL-10 $(27,41,53,54,60,75)$. Noticeably, the negative regulation is also a key factor in inducing the exhaustion of $\mathrm{CD}^{+} \mathrm{T}$ and NK cells, resulting in the immune escape of HBV and HCC tumor cells $(26,40,63,73)$. Additionally, the protective antibody production of B cells was also inhibited by Kupffer cell-derived IL-10 (72). How to control and maintain the immune balance is a key issue in the treatment of HBV-related HCC.

\section{Immune-Based Approaches to HBV-Related HCC Therapy}

When the disease cycle of inflammation, progressive fibrosis, cirrhosis and regeneration is broken, the pathways to HCC development are interrupted. It has been recognized that immune balance is important to the outcome of HBV infection, and the effective immune responses with sufficient magnitude and quality of the HBV-specific immune cells is able to adequately control HBV (12). Two clinical cases have further confirmed this speculation. HBV can be eliminated from the infected liver in the recipients with pre-existing HBV immunity when transplanted with a liver from the donor of chronic HBV infection (91). Moreover, after bone marrow transplantation, patients with chronic HBV infection develop an effective anti-HBV immune response in their body and clear $\operatorname{HBV}(92,93)$. Based on these increasing understanding of the mechanisms of immune pathogenesis in patients with chronic HBV infection and HBV-associated HCC, immune-based therapies able to restore immunity and consequently eliminate HBV has been proposed and promoted. Such strategies include checkpoint inhibition, genetically modified $\mathrm{T}$ cell transfer, therapeutic vaccines and metabolic modulation.

\section{Checkpoint Inhibition}

In HBV-infected patients, the function of $\mathrm{PD}-1^{+} \mathrm{HBV}$-specific $\mathrm{CD}^{+}{ }^{+} \mathrm{T}$ cells and $\mathrm{PD}-1^{+} \mathrm{HBV}$-specific $\mathrm{CD} 4^{+} \mathrm{T}$ cells were suppressed by the expression of inhibitory ligands on several kinds of immune cells including HSCs, liver endothelial sinusoidal cells, liver-resident macrophages and dendritic cells. By using checkpoint inhibitors to block PD-1/PD-L1 function, HBV-specific $T$ cells were reactivated and their functions were improved $(21,22)$. Furthermore, a combination therapy involving simultaneous stimulation of OX40 and blockade of PD-L1 functionally augmented $\mathrm{HBV}$-specific $\mathrm{CD} 4^{+} \mathrm{T}$ cells to produce IFN- $\gamma$ and IL-21 (84). HBV-specific B cell response would be promoted by the activated $\mathrm{CD} 4^{+} \mathrm{T}$ cells in patients with chronic HBV infection $(50,51)$. CTLA-4 and TIM-3 may offer alternative potential immunotherapeutic targets for patients with HBV chronic infection, since these immune inhibitory receptors also correlated to the inactivation of HBV-specific T cells (94). Higher TIGIT expression was observed in the tumor region of HCC patients and was potentially linked to tumor progression. However, prior to the appearance of a tumor in the liver tissue, TIGIT maintains hepatic adaptive immunotolerance and delays tumor initiation (37). Consequently, the distinct roles of TIGIT in the various stages of tumor initiation and progression should be accounted for the use of checkpoint inhibitors.

\section{Genetically Modified T Cell Therapy}

In HBV-related HCCs, the HBV DNA integration into the host genomes leads to the expression of HBV antigens on HCC cells, which can be presented by specific MHC molecules and subsequently recognized by $\mathrm{HBV}$-specific $\mathrm{CD}^{+} \mathrm{T}$ cells. Autologous T cells that are genetically modified to express HBV antigen-specific $\mathrm{T}$ cell receptor (TCR) were used to control HBVrelated HCC in patients, such as HBsAg-specific TCR-redirected $\mathrm{T}$ cells targeted $\mathrm{HBsAg}^{+} \mathrm{HCC}$ tumor cells and reconstitute 
TABLE 1 | HBV-induced changed immune cells and released cytokines.

\begin{tabular}{|c|c|c|}
\hline Immune cells & Released cytokines & References \\
\hline $\mathrm{CD} 4+\mathrm{T}$ cells & IFN- $\gamma$, IL-21, IL-17 & $(39,84,85)$ \\
\hline NKT cells & IFN- $\gamma$, IL-4, IL-13 & $(12,68,70)$ \\
\hline Macrophages & IFN- $\gamma$, IL-6, MCP-1,IL-1 $\beta$, TNF- $\alpha$, CXCL10 & $(38,87)$ \\
\hline$\gamma \delta T$ cells & $\mathrm{IL}-17, \mathrm{TNF}-\alpha$ & $(75,88)$ \\
\hline Kupffer cells & IL-10, TGF- $\beta$, IL-12, IL-6, TNF- $\alpha$ & $(70,72,73,89)$ \\
\hline Regulatory T cells (Tregs) & IL-10, TGF- $\beta$, IL-35 & $(27,40,41)$ \\
\hline Regulatory B cells (Bregs) & IL-10 & $(54,90)$ \\
\hline
\end{tabular}

\section{Chronic HBV infection}

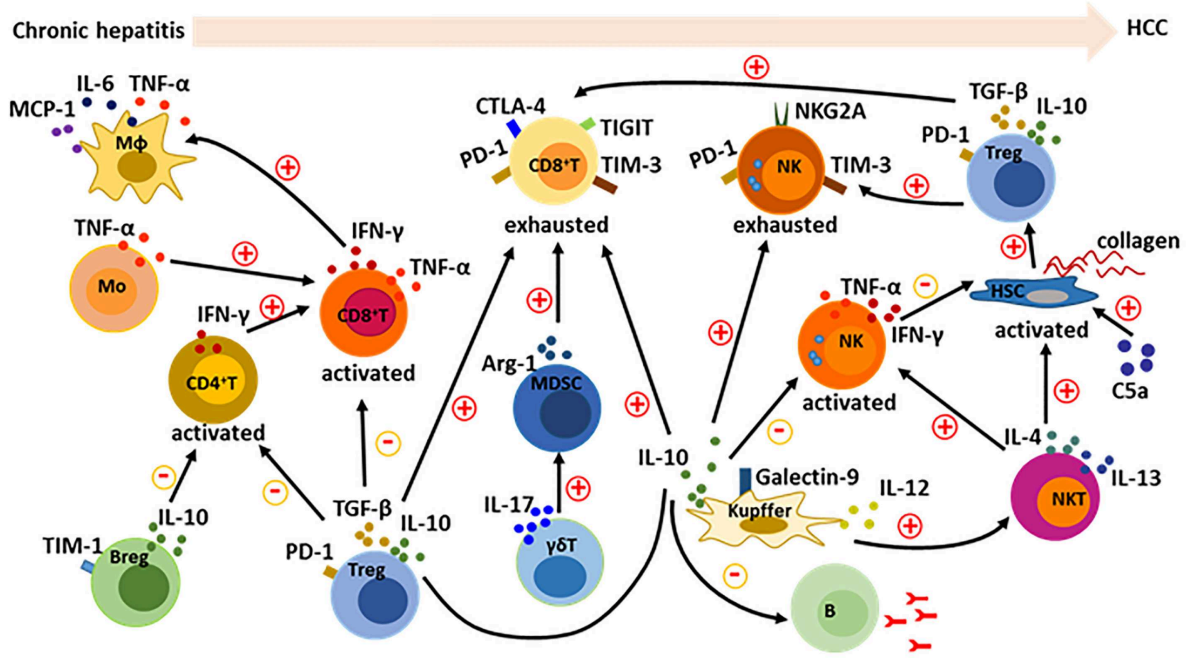

FIGURE 3 | Cross-talk among immune cells in the development of HBV-related HCC. During chronic HBV infection, there are complicate interactions among immune cells. Activation of $\mathrm{CD}^{+}{ }^{+} \mathrm{T}$ cells is enhanced by $\mathrm{CD} 4^{+} \mathrm{T}$ and monocytes; and then activated $\mathrm{CD} 8^{+} \mathrm{T}$ cells recruit and activate macrophages. Activation of NKT cells can be promoted by Kupffer cells, and further activate NK cells and HSCs. On the other hand, suppressive Tregs, Kupffer cells and Bregs inhibit the activation of $\mathrm{CD}^{+}{ }^{+} \mathrm{T}, \mathrm{CD} 8^{+} \mathrm{T}$, and NK cells. Furthermore, Tregs, Kupffer cells, and MDSCs contribute to the formation of exhausted CD8 ${ }^{+} \mathrm{T}$ and NK cells. A variety of cytokines including IFN- $\gamma$, TNF- $\alpha$, IL-6, MCP-1, IL-4, IL-13, IL-12, IL-17, IL-10, and TGF- $\beta$ are involved in the cross-talk between immune cells. Additionally, complement protein such as C5a positive regulate the activation of HSCs.

anti-tumoral immune responses $(95,96)$. HLA-A*02-restricted HBV envelope- or core-specific TCRs cloned from patients with acute or resolved HBV infection were used to genetically modify $\mathrm{T}$ cells with high functional avidity, demonstrating these envelope- or core-specific TCR-transduced T cells could effectively kill hepatoma cells replicating HBV (97). Further work showed that persistently infected hepatocytes carrying HBV cccDNA could be eliminated by redirecting cytolytic T cells against HBsAg-producing cells (98). The first successful clinic trial of HBV-TCR redirected T cell therapy was from a liver transplant patient with extrahepatic HCC metastasis which produced HBsAg due to the HBV DNA integration of tumor cells (96). Since HLA mismatched in the transplant liver, the HBVTCR redirected T cells only attacked the extrahepatic tumor cells but not the normal hepatocytes. However, in HBV-related HCC patients there are $\mathrm{HBsAg}^{+}$normal hepatocytes and $\mathrm{HBsAg}^{+}$ transformed cells, thus HBV-TCR redirected T cells may induce sever liver damage by targeting $\mathrm{HBsAg}^{+}$normal hepatocytes. How to reduce this risk and overcome the drawback deserves further investigation (99). Additionally, non-lytic lymphocytes engineered to express HBV-specific TCR could reduce HBV replication and limit $\mathrm{HBV}$ infection by activating apolipoprotein B mRNA editing enzyme, catalytic polypeptide 3 (APOBEC3) (100). These findings suggest that redirecting $\mathrm{T}$ cells genetically modified with high functional TCRs may be therapeutic potential in the treatment of CHB and HBV-related HCC.

\section{Therapeutic Vaccines}

In chronic $\mathrm{HBV}$ infection, a therapeutic vaccine against $\mathrm{HBV}$ is primarily able to break $\mathrm{HBV}$-specific immune tolerance and elicit 
an effective immune response. The combination of a therapeutic vaccine (GS-4774) that HBV antigens were engineered to express in yeast and tenofovir disoproxil fumarate (TDF) was shown to improve $\mathrm{HBV}$-specific $\mathrm{CD} 8^{+} \mathrm{T}$ cell responses, strongly with increased cytokine production of IFN- $\gamma$, TNF- $\alpha$ and IL-2 to boost the anti-virus immune responses in CHB patients (80). Treatment of GS-4774 resulted in the reduction of Treg numbers in these patients, potentially offering beneficial effects from both single and combination therapy for $\mathrm{CHB}$ patients (80).

\section{Metabolic Modulation}

In tumor microenvironment, the suppression of $\mathrm{T}$ cell metabolism by lack of nutrients or accumulation of lactate, lactic acid and kynurenine resulted in the inhibited effector $\mathrm{T}$ cell activity and the promoted suppressive Treg cell function (101). Consistent with the progression on the metabolic dysregulation on immune cells by chronic HBV infection, a novel reconstitution therapy by metabolic modulation might be promising for HBV-related HCC. Targeting exhausted $\mathrm{CD}^{+} \mathrm{T}$ cells by mitochondrion-targeted antioxidants such as mitoquinone (MitoQ) and piperidine-nitroxide (Mito Tempo) rescued their anti-viral activity demonstrated by significantly enhanced production of IFN- $\gamma$ and TNF- $\alpha$, especially the presence of double positive IFN- $\gamma^{+}$TNF- $\alpha^{+} \mathrm{CD} 8^{+}$T cells (29). Similar effects of the metabolic modulation were also observed in $\mathrm{CD}^{+}{ }^{+} \mathrm{T}$ cells. Regarding the restoration, metabolic modulation by mitochondrion-targeted antioxidants was effective on exhausted $\mathrm{T}$ cells in patients with chronic HBV infection, but not on function-competent $\mathrm{T}$ cells, which will reduce the risk of indiscriminate $\mathrm{T}$ cell amplification and antoimmune reactions in vivo when patients were treated. Additionally, the metabolic status of the $\mathrm{T}$ cells significantly affects their anti-viral and anti-tumor activity, such as in adoptive transfer of genetically

\section{REFERENCES}

1. Venook AP, Papandreou C, Furuse J, de Guevara LL. The incidence and epidemiology of hepatocellular carcinoma: a global and regional perspective. Oncologist. (2010)15 (Suppl. 4):5-13. doi: 10.1634/theoncologist.2010-S4-05

2. Rehermann B, Thimme R. Insights from antiviral therapy into immune responses to hepatitis B and C virus infection. Gastroenterology. (2019) 156:369-83. doi: 10.1053/j.gastro.2018.08.061

3. Alter HJ, Chisari FV. Is elimination of hepatitis B and C a pipe dream or reality? Gastroenterology. (2019) 156:2946. doi: 10.1053/j.gastro.2018.12.015

4. Rehermann B. Pathogenesis of chronic viral hepatitis: differential roles of T cells and NK cells. Nat Med. (2013) 19:859-68. doi: 10.1038/nm.3251

5. Levrero M, Zucman-Rossi J. Mechanisms of HBV-induced hepatocellular carcinoma. J Hepatol. (2016) 64:S84-101. doi: 10.1016/j.jhep.2016.02.021

6. Musa J, Li J, Grunewald TG. Hepatitis B virus large surface protein is priming for hepatocellular carcinoma development via induction of cytokinesis failure. J Pathol. (2019) 247:6-8. doi: 10.1002/path.5169

7. Guidotti LG, Rochford R, Chung J, Shapiro M, Purcell R, Chisari FV. Viral clearance without destruction of infected cells during acute HBV infection. Science. (1999) 284:825-9. doi: 10.1126/science.284.5415.825

8. Guidotti LG, Chisari FV. Noncytolytic control of viral infections by the innate and adaptive immune response. Annu Rev Immunol. (2001) 19:6591. doi: 10.1146/annurev.immunol.19.1.65 modified $\mathrm{T}$ cells. Thus, the effects of immunotherapy may be improved by combination of these two strategies.

\section{SUMMARY}

During chronic HBV infection, the immune imbalance at a cellular and molecular level is highly complex. Although our understanding of HBV immunopathogenesis has improved in recent years, the precise mechanisms governing this disease progression require further investigation. $\mathrm{HBV}$-specific $\mathrm{CD}^{+}$ T cells, HBV-non-specific $\mathrm{CD}^{+}{ }^{+}, \mathrm{CD} 4^{+} \mathrm{T}, \mathrm{B}, \mathrm{NK} / \mathrm{NKT}$, Kupffer cells, and HSCs are all involved in the development of HBVrelated HCC. Furthermore, cell-to-cell interactions and the regulations between these immune cells increase the complexity of HBV immunopathogenesis. Based on these progression, the potential strategies for the intervention and treatment of HBV-related HCC operate to boost the magnitude and quality of the HBV-specific immune responses with the aim of eliminating $\mathrm{HBV}$ and maintaining immune homeostasis in patients.

\section{AUTHOR CONTRIBUTIONS}

YC prepared and wrote the manuscript. ZT directed the content and revised the manuscript.

\section{FUNDING}

This work was supported by the Chinese Academy of Sciences (XDB29030201), National Natural Science Foundation of China (Grant No. 81788101, 81671554, 81821001, 91542000), and the Ministry of Science \& Technology of China (2017ZX10202203002-001, 2017ZX10202203-009-002).

9. Thimme R, Wieland S, Steiger C, Ghrayeb J, Reimann KA, Purcell $\mathrm{RH}$, et al. $\mathrm{CD}^{+} \mathrm{T}$ cells mediate viral clearance and disease pathogenesis during acute hepatitis B virus infection. J Virol. (2003) 77:68-76. doi: 10.1128/JVI.77.1.68-76.2003

10. Ando K, Moriyama T, Guidotti LG, Wirth S, Schreiber RD, Schlicht HJ, et al. Mechanisms of class I restricted immunopathology. A transgenic mouse model of fulminant hepatitis. J Exp Med. (1993) 178:154154. doi: 10.1084/jem.178.5.1541

11. Maini MK, Boni C, Lee CK, Larrubia JR, Reignat S, Ogg GS, et al. The role of virus-specific $\mathrm{CD}^{+}$cells in liver damage and viral control during persistent hepatitis B virus infection. J Exp Med. (2000) 191:126980. doi: 10.1084/jem.191.8.1269

12. Gehring AJ, Protzer U. Targeting innate and adaptive immune responses to cure chronic HBV infection. Gastroenterology. (2019) 156:325-37. doi: 10.1053/j.gastro.2018.10.032

13. Mason WS, Gill US, Litwin S, Zhou Y, Peri S, Pop O, et al. $\mathrm{HBV}$ DNA integration and clonal hepatocyte expansion in chronic hepatitis B patients considered immune tolerant. Gastroenterology. (2016) 151:986-98. doi: 10.1053/j.gastro.2016. 07.012

14. Su IJ, Hsieh WC, Tsai HW, Wu HC. Chemoprevention and novel therapy for hepatocellular carcinoma associated with chronic hepatitis B virus infection. Hepatobiliary Surg Nutr. (2013) 2:37-9. doi: 10.3978/j.issn.2304-3881.2012.10.08 
15. Kim GA, Lim YS, Han S, Choi J, Shim JH, Kim KM, et al. High risk of hepatocellular carcinoma and death in patients with immune-tolerantphase chronic hepatitis B. Gut. (2018) 67:945-52. doi: 10.1136/gutjnl-2017-3 14904

16. Bertoletti A, Kennedy PTF, Durantel D. HBV infection and HCC: the 'dangerous liaisons'. Gut. (2018) 67:787-8. doi: 10.1136/gutjnl-2017-315528

17. Zhu H, Cao X. NLR members in inflammation-associated carcinogenesis. Cell Mol Immunol. (2017) 14:403. doi: 10.1038/cmi.2017.14

18. Rehermann B, Ferrari C, Pasquinelli C, Chisari FV. The hepatitis B virus persists for decades after patients' recovery from acute viral hepatitis despite active maintenance of a cytotoxic T-lymphocyte response. Nat Med. (1996) 2:1104-8. doi: 10.1038/nm1096-1104

19. Webster GJ, Reignat S, Brown D, Ogg GS, Jones L, Seneviratne SL, et al. Longitudinal analysis of $\mathrm{CD}^{+} \mathrm{T}$ cells specific for structural and nonstructural hepatitis $\mathrm{B}$ virus proteins in patients with chronic hepatitis B: implications for immunotherapy. J Virol. (2004) 78:570719. doi: 10.1128/JVI.78.11.5707-5719.2004

20. Park JJ, Wong DK, Wahed AS, Lee WM, Feld JJ, Terrault N, et al. Hepatitis B virus-Specific and global T-cell dysfunction in chronic hepatitis B. Gastroenterology. (2016) 150:684-95. doi: 10.1053/j.gastro.2015.11.050

21. Boni C, Fisicaro P, Valdatta C, Amadei B, Di Vincenzo P, Giuberti $\mathrm{T}$, et al. Characterization of hepatitis $\mathrm{B}$ virus (HBV)-specific T-cell dysfunction in chronic HBV infection. J Virol. (2007) 81:4215-25. doi: 10.1128/JVI.02844-06

22. Fisicaro P, Valdatta C, Massari M, Loggi E, Biasini E, Sacchelli L, et al. Antiviral intrahepatic T-cell responses can be restored by blocking programmed death-1 pathway in chronic hepatitis B. Gastroenterology. (2010) 138:682-93. doi: 10.1053/j.gastro.2009.09.052

23. Wherry EJ. T cell exhaustion. Nat Immunol. (2011) 12:4929. doi: $10.1038 /$ ni.2035

24. Mohammadizad H, Shahbazi M, Hasanjani Roushan MR, SoltanzadehYamchi M, Mohammadnia-Afrouzi M. TIM-3 as a marker of exhaustion in $\mathrm{CD}^{+} \mathrm{T}$ cells of active chronic hepatitis B patients. Microb Pathog. (2019) 128:323-8. doi: 10.1016/j.micpath.2019.01.026

25. Sun C, Lan P, Han Q, Huang M, Zhang Z, Xu G, et al. Oncofetal gene SALL4 reactivation by hepatitis $B$ virus counteracts miR200c in PD-L1-induced $\mathrm{T}$ cell exhaustion. Nat Commun. (2018) 9:1241. doi: 10.1038/s41467-018-03584-3

26. Wang Q, Pan W, Liu Y, Luo J, Zhu D, Lu Y, et al. Hepatitis B virus-specific $\mathrm{CD}^{+} \mathrm{T}$ cells maintain functional exhaustion after antigen reexposure in an acute activation immune environment. Front Immunol. (2018) 9:219. doi: 10.3389/fimmu.2018.00219

27. Lim CJ, Lee YH, Pan L, Lai L, Chua C, Wasser $M$, et al. Multidimensional analyses reveal distinct immune microenvironment in hepatitis B virus-related hepatocellular carcinoma. Gut. (2019) 68:916-27. doi: 10.1136/gutjnl-2018-316510

28. Zheng C, Zheng L, Yoo JK, Guo H, Zhang Y, Guo X, et al. Landscape of infiltrating $\mathrm{T}$ cells in liver cancer revealed by single-cell sequencing. Cell. (2017) 169:1342-56. doi: 10.1016/j.cell.2017.05.035

29. Fisicaro P, Barili V, Montanini B, Acerbi G, Ferracin M, Guerrieri F, et al. Targeting mitochondrial dysfunction can restore antiviral activity of exhausted HBV-specific CD8 T cells in chronic hepatitis B. Nat Med. (2017) 23:327-36. doi: 10.1038/nm.4275

30. Masson JJ, Billings HW, Palmer CS. Metabolic reprogramming during hepatitis $\mathrm{B}$ disease progression offers novel diagnostic and therapeutic opportunities. Antivir Chem Chemother. (2017) 25:53-57. doi: 10.1177/2040206617701372

31. Schuch A, Salimi Alizei E, Heim K, Wieland D, Kiraithe MM, Kemming $\mathrm{J}$, et al. Phenotypic and functional differences of HBV core-specific versus $\mathrm{HBV}$ polymerase-specific CD ${ }^{+}{ }^{+}$cells in chronically $\mathrm{HBV}$-infected patients with low viral load. Gut. (2019) 68:905-15. doi: 10.1136/gutjnl-2018-3 16641

32. Hoogeveen RC, Robidoux MP, Schwarz T, Heydmann L, Cheney JA, Kvistad $\mathrm{D}$, et al. Phenotype and function of HBV-specific $\mathrm{T}$ cells is determined by the targeted epitope in addition to the stage of infection. Gut. (2019) 68:893-904. doi: 10.1136/gutjnl-2018-316644

33. Reignat S, Webster GJ, Brown D, Ogg GS, King A, Seneviratne SL, et al. Escaping high viral load exhaustion: CD8 cells with altered tetramer binding in chronic hepatitis B virus infection. J Exp Med. (2002) 195:1089101. doi: 10.1084/jem.20011723

34. Cheng Y, Zhu YO, Becht E, Aw P, Chen J, Poidinger M, et al. Multifactorial heterogeneity of virus-specific T cells and association with the progression of human chronic hepatitis B infection. Sci Immunol. (2019) 4:aau6905. doi: 10.1126/sciimmunol.aau6905

35. Nakamoto Y, Guidotti LG, Kuhlen CV, Fowler P, Chisari FV. Immune pathogenesis of hepatocellular carcinoma. J Exp Med. (1998) 188:34150. doi: 10.1084/jem.188.2.341

36. Nakamoto Y, Kaneko S, Fan H, Momoi T, Tsutsui H, Nakanishi K, et al. Prevention of hepatocellular carcinoma development associated with chronic hepatitis by anti-fas ligand antibody therapy. J Exp Med. (2002) 196:1105-11. doi: 10.1084/jem.20020633

37. Zong L, Peng H, Sun C, Li F, Zheng M, Chen Y, et al. Breakdown of adaptive immunotolerance induces hepatocellular carcinoma in HBsAg-tg mice. Nat Commun. (2019) 10:221. doi: 10.1038/s41467-018-08096-8

38. Wang J, Zhao W, Cheng L, Guo M, Li D, Li X, et al. CD137mediated pathogenesis from chronic hepatitis to hepatocellular carcinoma in hepatitis B virus-transgenic mice. J Immunol. (2010) 185:765462. doi: 10.4049/jimmunol.1000927

39. Fu J, Zhang Z, Zhou L, Qi Z, Xing S, Lv J, et al. Impairment of $\mathrm{CD}^{+}{ }^{+}$cytotoxic $\mathrm{T}$ cells predicts poor survival and high recurrence rates in patients with hepatocellular carcinoma. Hepatology. (2013) 58:13949. doi: 10.1002/hep. 26054

40. Trehanpati N, Vyas AK. Immune regulation by T regulatory cells in hepatitis B virus-related inflammation and cancer. Scand J Immunol. (2017) 85:17581. doi: $10.1111 /$ sji.12524

41. $\mathrm{Fu} \mathrm{J,} \mathrm{Xu} \mathrm{D}$, Liu Z, Shi $\mathrm{M}$, Zhao $\mathrm{P}, \mathrm{Fu} \mathrm{B}$, et al. Increased regulatory $\mathrm{T}$ cells correlate with CD8 T-cell impairment and poor survival in hepatocellular carcinoma patients. Gastroenterology. (2007) 132:232839. doi: 10.1053/j.gastro.2007.03.102

42. Yang P, Li QJ, Feng Y, Zhang Y, Markowitz GJ, Ning S, et al. TGF-betamiR-34a-CCL22 signaling-induced Treg cell recruitment promotes venous metastases of HBV-positive hepatocellular carcinoma. Cancer Cell. (2012) 22:291-303. doi: 10.1016/j.ccr.2012.07.023

43. Zhang $\mathrm{HH}$, Mei MH, Fei R, Liu F, Wang JH, Liao WJ, et al. Regulatory $\mathrm{T}$ cells in chronic hepatitis $\mathrm{B}$ patients affect the immunopathogenesis of hepatocellular carcinoma by suppressing the anti-tumour immune responses. J Viral Hepat. (2010) 17:34-43. doi: 10.1111/j.1365-2893.2010.01269.x

44. Chen T, Song D, Min Z, Wang X, Gu Y, Wei B, et al. Perioperative dynamic alterations in peripheral regulatory $\mathrm{T}$ and $\mathrm{B}$ cells in patients with hepatocellular carcinoma. J Transl Med. (2012) 10:14. doi: 10.1186/1479-5876-10-14

45. Yang J, Li L. $\mathrm{CD} 4{ }^{+} \mathrm{CD} 25^{+}$regulatory T-cells: a potential target for treating patients with chronic HBV infection. Cell Mol Immunol. (2017) 14:8001. doi: $10.1038 / \mathrm{cmi} .2017 .67$

46. Jia Y, Zeng $\mathrm{Z}$, Li $\mathrm{Y}$, Li Z, Jin $\mathrm{L}$, Zhang $\mathrm{Z}$, et al. Impaired function of $\mathrm{CD}^{+} \mathrm{T}$ follicular helper (Tfh) cells associated with hepatocellular carcinoma progression. PLOS ONE. (2015) 10:e0117458. doi: 10.1371/journal.pone.0117458

47. Zhou ZQ, Tong DN, Guan J, Tan HW, Zhao LD, Zhu Y, et al. Follicular helper $\mathrm{T}$ cell exhaustion induced by PD-L1 expression in hepatocellular carcinoma results in impaired cytokine expression and B cell help, and is associated with advanced tumor stages. Am J Transl Res. (2016) 8:2926-36.

48. Bertoletti A, Ferrari C. Adaptive immunity in HBV infection. J Hepatol. (2016) 64:S71-83. doi: 10.1016/j.jhep.2016.01.026

49. Zhang S, Zhao J, Zhang Z. Humoral immunity, the underestimated player in hepatitis B. Cell Mol Immunol. (2018) 15:645-8. doi: 10.1038/cmi.2017.132

50. Salimzadeh L, Le Bert N, Dutertre CA, Gill US, Newell EW, Frey C, et al. PD-1 blockade partially recovers dysfunctional virus-specific $B$ cells in chronic hepatitis B infection. J Clin Invest. (2018) 128:457387. doi: 10.1172/JCI121957

51. Burton AR, Pallett LJ, McCoy LE, Suveizdyte K, Amin OE, Swadling L, et al. Circulating and intrahepatic antiviral B cells are defective in hepatitis B. Clin Invest. (2018) 128:4588-603. doi: 10.1172/JCI121960

52. Perrillo RP, Gish R, Falck-Ytter YT. American Gastroenterological Association Institute technical review on prevention and treatment of 
hepatitis B virus reactivation during immunosuppressive drug therapy. Gastroenterology. (2015) 148:221-44. doi: 10.1053/j.gastro.2014.10.038

53. Xue H, Lin F, Tan H, Zhu ZQ, Zhang ZY, Zhao L. Overrepresentation of IL-10-expressing B cells suppresses cytotoxic $\mathrm{CD}^{+} \mathrm{T}$ cell activity in HBV-induced hepatocellular carcinoma. PLOS ONE. (2016) 11:e0154815. doi: 10.1371/journal.pone.0154815

54. Wang G, Liu Y, Huang R, Jia B, Su R, Sun Z, et al. Characteristics of regulatory $B$ cells in patients with chronic hepatitis $B$ virus infection in different immune phases. Discov Med. (2017) 23:295-304.

55. Gao B, Jeong WI, Tian Z. Liver: an organ with predominant innate immunity. Hepatology. (2008) 47:729-36. doi: 10.1002/hep.22034

56. Tian Z, Chen Y, Gao B. Natural killer cells in liver disease. Hepatology. (2013) 57:1654-62. doi: 10.1002/hep.26115

57. Peng H, Sun R. Liver-resident NK cells and their potential functions. Cell Mol Immunol. (2017) 890-4. doi: $10.1038 / \mathrm{cmi} .2017 .72$

58. He Y, Tian Z. NK cell education via nonclassical MHC and non-MHC ligands. Cell Mol Immunol. (2016) 321-30. doi: 10.1038/cmi.2016.26

59. Kakimi K, Guidotti LG, Koezuka Y, Chisari FV. Natural killer T cell activation inhibits hepatitis B virus replication in vivo. J Exp Med. (2000) 192:921-30. doi: 10.1084/jem.192.7.921

60. Peppa D, Micco L, Javaid A, Kennedy PT, Schurich A, Dunn C, et al. Blockade of immunosuppressive cytokines restores NK cell antiviral function in chronic hepatitis B virus infection. PLoS Pathog. (2010) 6:e1001227. doi: 10.1371/journal.ppat.1001227

61. Yang Y, Han Q, Hou Z, Zhang C, Tian Z, Zhang J. Exosomes mediate hepatitis $\mathrm{B}$ virus (HBV) transmission and NK-cell dysfunction. Cell Mol Immunol. (2017) 14:465-75. doi: 10.1038/cmi.2016.24

62. Sun C, Sun HY, Xiao WH, Zhang C, Tian ZG. Natural killer cell dysfunction in hepatocellular carcinoma and NK cell-based immunotherapy. Acta Pharmacol Sin. (2015) 36:1191-9. doi: 10.1038/aps.2015.41

63. Zhang QF, Yin WW, Xia Y, Yi YY, He QF, Wang X, et al. Liver-infiltrating CD11b(-)CD27(-) NK subsets account for NK-cell dysfunction in patients with hepatocellular carcinoma and are associated with tumor progression. Cell Mol Immunol. (2017) 819-29. doi: 10.1038/cmi.2016.28

64. Xu D, Han Q, Hou Z, Zhang C, Zhang J. miR-146a negatively regulates NK cell functions via STAT1 signaling. Cell Mol Immunol. (2017) 71220. doi: $10.1038 / \mathrm{cmi} .2015 .113$

65. Maini MK, Peppa D. NK cells: a double-edged sword in chronic hepatitis B virus infection. Front Immunol. (2013) 57. doi: 10.3389/fimmu.2013.00057

66. Chen Y, Hao X, Sun R, Wei H, Tian Z. Natural killer cell-derived interferon-gamma promotes hepatocellular carcinoma through the epithelial cell adhesion molecule-epithelial-to-mesenchymal transition axis in hepatitis B virus transgenic mice. Hepatology. (2019) 69:1735-50. doi: 10.1002/hep.30317

67. Attallah AM, El-Far M, Zahran F, Shiha GE, Farid K, Omran MM, et al. Interferon-gamma is associated with hepatic dysfunction in fibrosis, cirrhosis, hepatocellular carcinoma. J Immunoassay Immunochem. (2016) 37:597-610. doi: 10.1080/15321819.2016.1179646

68. Jin Z, Sun R, Wei H, Gao X, Chen Y, Tian Z. Accelerated liver fibrosis in hepatitis B virus transgenic mice: involvement of natural killer $\mathrm{T}$ cells. Hepatology. (2011) 53:219-29. doi: 10.1002/hep.23983

69. Li X, Su Y, Hua X, Xie C, Liu J, Huang Y, et al. Levels of hepatic Th17 cells and regulatory $\mathrm{T}$ cells upregulated by hepatic stellate cells in advanced HBV-related liver fibrosis. J Transl Med. (2017) 15:75. doi: 10.1186/s12967-017-1167-y

70. Hou X, Hao X, Zheng M, Xu C, Wang J, Zhou R, et al. CD205-TLR9IL-12 axis contributes to CpG-induced oversensitive liver injury in HBsAg transgenic mice by promoting the interaction of NKT cells with Kupffer cells. Cell Mol Immunol. (2017) 14:675-84. doi: 10.1038/cmi.2015.111

71. Wu LL, Peng WH, Wu HL, Miaw SC, Yeh SH, Yang HC, et al. Lymphocyte antigen 6 complex, locus $\mathrm{C}^{+}$monocytes and kupffer cells orchestrate liver immune responses against hepatitis B virus in mice. Hepatology. (2019) 69:2364-80. doi: 10.1002/hep.30510

72. Xu L, Yin W, Sun R, Wei H, Tian Z. Kupffer cell-derived IL-10 plays a key role in maintaining humoral immune tolerance in hepatitis B virus-persistent mice. Hepatology. (2014) 59:443-52. doi: 10.1002/hep.26668

73. Li M, Sun R, Xu L, Yin W, Chen Y, Zheng X, et al. Kupffer cells support hepatitis $\mathrm{B}$ virus-mediated $\mathrm{CD} 8^{+} \mathrm{T}$ cell exhaustion via hepatitis
B core antigen-TLR2 interactions in mice. J Immunol. (2015) 195:31009. doi: 10.4049/jimmunol.1500839

74. Tian Y, Kuo CF, Akbari O, Ou JH. Maternal-derived hepatitis B virus e antigen alters macrophage function in offspring to drive viral persistence after vertical transmission. Immunity. (2016) 44:120414. doi: 10.1016/j.immuni.2016.04.008

75. Kong X, Sun R, Chen Y, Wei H, Tian Z. gammadeltaT cells drive myeloid-derived suppressor cell-mediated $\mathrm{CD}^{+} \mathrm{T}$ cell exhaustion in hepatitis B virus-induced immunotolerance. J Immunol. (2014) 193:164553. doi: $10.4049 /$ jimmunol.1303432

76. Chang KM, Traum D, Park JJ, Ho S, Ojiro K, Wong DK, et al. Distinct phenotype and function of circulating Vdelta1 ${ }^{+}$and Vdelta2 ${ }^{+}$ gammadeltaT-cells in acute and chronic hepatitis B. PLoS Pathog. (2019) 15:e1007715. doi: 10.1371/journal.ppat.1007715

77. Xu R, Lin F, He J, Jin L, Zhang JY, Fu J, et al. Complement 5a stimulates hepatic stellate cells in vitro, and is increased in the plasma of patients with chronic hepatitis B. Immunology. (2013) 138:22834. doi: 10.1111/imm.12024

78. Luo J, Chen S, Wang J, Ou S, Zhang W, Liu Y, et al. Genetic polymorphisms in complement receptor 1 gene and its association with HBV-related liver disease: a case-control study. Gene. (2019) 688:10718. doi: 10.1016/j.gene.2018.11.082

79. Shan C, Zhang S, Cui W, You X, Kong G, Du Y, et al. Hepatitis B virus X protein activates CD59 involving DNA binding and let-7i in protection of hepatoma and hepatic cells from complement attack. Carcinogenesis. (2011) 32:1190-7. doi: 10.1093/carcin/bgr106

80. Boni C, Janssen H, Rossi M, Yoon SK, Vecchi A, Barili V, et al. Combined GS-4774 and tenofovir therapy can improve HBV-specific Tcell responses in patients with chronic hepatitis. Gastroenterology. (2019) 157:227-41. doi: 10.1053/j.gastro.2019.03.044

81. Fioravanti J, Di Lucia P, Magini D, Moalli F, Boni C, Benechet $\mathrm{AP}$, et al. Effector $\mathrm{CD}^{+} \mathrm{T}$ cell-derived interleukin10 enhances acute liver immunopathology. J Hepatol. (2017) 67:543-8. doi: 10.1016/j.jhep.2017.04.020

82. Zhang GL, Zhang T, Zhao QY, Xie C, Lin CS, Gao ZL. Increased IL-17producing $\mathrm{CD}^{+} \mathrm{T}$ cell frequency predicts short-term mortality in patients with hepatitis B virus-related acute-on-chronic liver failure. Ther Clin Risk Manag. (2018) 14:2127-36. doi: 10.2147/TCRM.S184809

83. Jiang H, Li L, Han J, Sun Z, Rong Y, Jin Y. CXCR5 ${ }^{+} \mathrm{CD}^{+} \mathrm{T}$ cells indirectly offer B cell help and are inversely correlated with viral load in chronic hepatitis B infection. DNA Cell Biol. (2017) 36:3217. doi: $10.1089 /$ dna.2016.3571

84. Jacobi FJ, Wild K, Smits M, Zoldan K, Csernalabics B, Flecken T, et al. OX40 stimulation and PD-L1 blockade synergistically augment HBVspecific CD4 T cells in patients with HBeAg-negative infection. J Hepatol. (2019):1103-13. doi: 10.1016/j.jhep.2019.02.016

85. Liu Y, Li L, Liu J, She WM, Shi JM, Li J, et al. Activated hepatic stellate cells directly induce pathogenic Th17 cells in chronic hepatitis B virus infection. Exp Cell Res. (2017) 359:129-37. doi: 10.1016/j.yexcr.2017.08.001

86. Li H, Zhai N, Wang Z, Song H, Yang Y, Cui A, et al. Regulatory NK cells mediated between immunosuppressive monocytes and dysfunctional $\mathrm{T}$ cells in chronic HBV infection. Gut. (2018) 67:2035-44. doi: 10.1136/gutjnl-2017-314098

87. Cheng X, Xia Y, Serti E, Block PD, Chung M, Chayama K, et al. Hepatitis B virus evades innate immunity of hepatocytes but activates cytokine production by macrophages. Hepatology. (2017) 66:1779-93. doi: 10.1002/hep.29348

88. Chen M, Hu P, Peng H, Zeng W, Shi X, Lei Y, et al. Enhanced peripheral gammadelta $\mathrm{T}$ cells cytotoxicity potential in patients with HBV-associated acute-on-chronic liver failure might contribute to the disease progression. J Clin Immunol. (2012) 32:877-85. doi: 10.1007/s10875-012-9678-z

89. Boltjes A, van Montfoort N, Biesta PJ, Op den Brouw ML, Kwekkeboom J, van der Laan LJ, et al. Kupffer cells interact with hepatitis B surface antigen in vivo and in vitro, leading to proinflammatory cytokine production and natural killer cell function. J Infect Dis. (2015) 211:126878. doi: 10.1093/infdis/jiu599

90. Wang L, Qiu J, Yu L, Hu X, Zhao P, Jiang Y. Increased numbers of $\mathrm{CD}^{+} \mathrm{CD} 19^{+} \mathrm{CD} 1$ dhighIL- $10^{+} \quad$ Bregs, $\mathrm{CD}^{+} \mathrm{Foxp}^{+}$Tregs, 
$\mathrm{CD}^{+}{ }^{+} \mathrm{CXCR}^{+}{ }^{\mathrm{Foxp}_{3}}{ }^{+}$follicular regulatory $\mathrm{T}$ (TFR) cells in $\mathrm{CHB}$ or CHC patients. J Transl Med. (2014) 12:251. doi: 10.1186/s12967-014-0251-9

91. Loggi E, Micco L, Ercolani G, Cucchetti A, Bihl FK, Grazi GL, et al. Liver transplantation from hepatitis B surface antigen positive donors: a safe way to expand the donor pool. J Hepatol. (2012) 56:57985. doi: 10.1016/j.jhep.2011.09.016

92. Lau GK, Lok AS, Liang RH, Lai CL, Chiu EK, Lau YL, et al. Clearance of hepatitis B surface antigen after bone marrow transplantation: role of adoptive immunity transfer. Hepatology. (1997) 25:1497-501. doi: 10.1002/hep.510250631

93. Lau GK, Suri D, Liang R, Rigopoulou EI, Thomas MG, Mullerova I, et al. Resolution of chronic hepatitis B and anti-HBs seroconversion in humans by adoptive transfer of immunity to hepatitis B core antigen. Gastroenterology. (2002) 122:614-24. doi: 10.1053/gast.2002.31887

94. Li Z, Li N, Li F, Zhou Z, Sang J, Chen Y, et al. Immune checkpoint proteins PD-1 and TIM-3 are both highly expressed in liver tissues and correlate with their gene polymorphisms in patients with HBV-related hepatocellular carcinoma. Medicine. (2016) 95:e5749. doi: 10.1097/MD.0000000000005749

95. Bertoletti A, Ferrari C. Innate and adaptive immune responses in chronic hepatitis B virus infections: towards restoration of immune control of viral infection. Gut. (2012) 61:1754-64. doi: 10.1136/gutjnl-2011-301073

96. Qasim W, Brunetto M, Gehring AJ, Xue SA, Schurich A, Khakpoor A, et al. Immunotherapy of HCC metastases with autologous $\mathrm{T}$ cell receptor redirected $\mathrm{T}$ cells, targeting HBsAg in a liver transplant patient. J Hepatol. (2015) 62:486-91. doi: 10.1016/j.jhep.2014.10.001

97. Wisskirchen K, Metzger K, Schreiber S, Asen T, Weigand L, Dargel C, et al. Isolation and functional characterization of hepatitis B virus-specific T-cell receptors as new tools for experimental and clinical use. PLoS ONE. (2017) 12:e0182936. doi: 10.1371/journal.pone.0182936

98. Bohne F, Chmielewski M, Ebert G, Wiegmann K, Kurschner T, Schulze A, et al. T cells redirected against hepatitis B virus surface proteins eliminate infected hepatocytes. Gastroenterology. (2008) 134:239-47. doi: 10.1053/j.gastro.2007.11.002

99. Koh S, Tan AT, Li L, Bertoletti A. Targeted therapy of hepatitis B virusrelated hepatocellular carcinoma: present and future. Diseases. (2016) 4:10. doi: $10.3390 /$ diseases 4010010

100. Koh S, Kah J, Tham CYL, Yang N, Ceccarello E, Chia A, et al. Nonlytic lymphocytes engineered to express virus-specific T-cell receptors limit HBV infection by activating APOBEC3. Gastroenterology. (2018) 155:18093. doi: 10.1053/j.gastro.2018.03.027

101. Beckermann KE, Dudzinski SO, Rathmell JC. Dysfunctional T cell metabolism in the tumor microenvironment. Cytokine Growth Factor Rev. (2017) 35:7-14. doi: 10.1016/j.cytogfr.2017.04.003

Conflict of Interest Statement: The authors declare that the research was conducted in the absence of any commercial or financial relationships that could be construed as a potential conflict of interest.

Copyright $(0) 2019$ Chen and Tian. This is an open-access article distributed under the terms of the Creative Commons Attribution License (CC BY). The use, distribution or reproduction in other forums is permitted, provided the original author(s) and the copyright owner(s) are credited and that the original publication in this journal is cited, in accordance with accepted academic practice. No use, distribution or reproduction is permitted which does not comply with these terms. 